\title{
Low head circumference during early childhood and its predictors in a semi- urban settlement of Vellore, Southern India
}

Kulandaipalayam Natarajan Sindhu', Prashanth Ramamurthy ${ }^{2 *}$, Karthikeyan Ramanujam', Ankita Henry', Joseph Dian Bondu ${ }^{3}$, Sushil Mathew John ${ }^{4}$, Sudhir Babji ${ }^{1}$, Beena Koshy ${ }^{5}$, Anuradha Bose ${ }^{6}$, Gagandeep Kang ${ }^{1}$ and Venkata Raghava Mohan ${ }^{6}$

\begin{abstract}
Background: Stunting in developing countries continues to be a major public health problem. Measuring head circumference $(\mathrm{HC})$ during clinical anthropometric assessment can help predict stunting. The aim of this study was to assess burden and determine the predictors of low $\mathrm{HC}(<-2 \mathrm{SD})$ at birth and during first 2 years of life in a semi- urban settlement of Vellore.

Methods: The study uses baseline data and serial HC measurements from the birth cohort of MAL-ED study, where 228 children from Vellore completed follow-up between March 2010 to February 2014. Analysis of baseline, maternal and paternal characteristics, micro-nutrient status and cognition with $\mathrm{HC}$ measurements was performed using STATA version 13.0 software.

Results: The mean HC ( \pm SD) at 1st, 12th and 24th month were $33.37(1.29) \mathrm{cm}, 42.76(1.23) \mathrm{cm}$ and $44.9(1.22) \mathrm{cm}$ respectively. A third of the infants (75/228) had HC less than -2 SD at first month of life, and on follow-up, 50\% of the cohort had $\mathrm{HC} \leq-2$ SD both at 12th and 24th month. Low HC measurements at all three time-points were observed for $21.6 \%(46 / 222)$ infants. Low HC was significantly associated with stunting in $37.3 \%(\mathrm{OR}=10.8), 57.3 \%$ $(\mathrm{OR}=3.1)$ and $44.4 \%(\mathrm{OR}=2.6)$ children at 1 st, 12 th and 24 th month respectively. Bivariate analysis of low HC $(<-2$ $\mathrm{SD})$ at 12th month showed a statistically significant association with lower socioeconomic status, low paternal and maternal $\mathrm{HC}$ and low maternal IQ. Multivariable logistic regression analysis showed maternal $(\mathrm{AOR}=0.759,95 \% \mathrm{Cl}=$ 0.604 to 0.954 ) and paternal ( $A O R=0.734,95 \% \mathrm{Cl}=0.581$ to 0.930 ) $\mathrm{HC}$ to be significantly associated with $\mathrm{HC}$ attained by the infant at the end of 12 months.

Conclusions: One-third of the children in our cohort had low head circumference $(\mathrm{HC})$ at birth, with one-fifth recording low HC at all time-points until 2 years of age. Low HC was significantly associated with stunting. Paternal and maternal $\mathrm{HC}$ predicted $\mathrm{HC}$ in children. HC measurement, often less used, can be a simple tool that can be additionally used by clinicians as well as parents/caregivers to monitor child growth.
\end{abstract}

Keywords: Head circumference measurement, Maternal head circumference, Paternal head circumference, Growth, Nutrition, India

\footnotetext{
* Correspondence: drprashanth@cmcvellore.ac.in

${ }^{2}$ Rural Unit for Health and Social Affairs, Christian Medical College, Vellore,

Tamil Nadu 632 209, India

Full list of author information is available at the end of the article
}

(c) The Author(s). 2019 Open Access This article is distributed under the terms of the Creative Commons Attribution 4.0 International License (http://creativecommons.org/licenses/by/4.0/), which permits unrestricted use, distribution, and reproduction in any medium, provided you give appropriate credit to the original author(s) and the source, provide a link to the Creative Commons license, and indicate if changes were made. The Creative Commons Public Domain Dedication waiver (http://creativecommons.org/publicdomain/zero/1.0/) applies to the data made available in this article, unless otherwise stated. 


\section{Background}

Even though stunting among children from the developing world is on a decline over the last two decades, it still continues to be a major public health problem [1, 2]. The Global Nutrition report 2017 has estimated that 155 million children are stunted across 72 countries, with two of every five stunted children living in South Asia [2]. In India, nearly one third of under-five children are stunted according to the recent National Family Health Survey-4 (NFHS-4) [3]. Growth monitoring through periodic anthropometric measurements serves as an alarm for growth faltering in children, thereby signalling the need for appropriate and timely action, and this has been a routine practice incorporated within the health systems of many countries. The three commonly used parameters for monitoring growth in children include weight, length/height and head circumference $(\mathrm{HC})$. However, measuring $\mathrm{HC}$ is not regularly done in many settings of developing countries, omitted even if done, with only weight and length/height measurements being predominantly taken in clinical anthropometric assessment and research studies [4].

Majority of the brain growth has been known to occur within the first two years of life and this steadily increases in volume up to adolescence. A low HC measurement can not only help predict and add on to the signs of stunting but can also predict brain development and cognition in children during their pre-school years [5]. Studies have shown that serial HC measurements during early childhood is a robust reflector of the brain volume and can help plot the trajectory of brain growth, thereby determining the cognitive functionality in later life [6-8]. A prospective study from Southern India has shown $\mathrm{HC}$ to be positively correlated with learning and visio-spatial ability in children aged 9 to 10 years [5]. Low $\mathrm{HC}$ measurements at birth and differential $\mathrm{HC}$ measurements in infants have also shown to be associated with social impairment, symptoms of autism spectrum disorders and motor delays later $[9,10]$.

Multiple factors influence $\mathrm{HC}$ in children through complex pathways, some of them being maternal education, maternal intelligent quotient, maternal body-massindex, socio-economic profile, birth weight, exclusive breast feeding, maternal smoking and others [11-17]. The height, weight and $\mathrm{HC}$ of parents, especially the maternal $\mathrm{HC}$, have also shown to significantly influence the $\mathrm{HC}$ of infants suggesting a strong intra-uterine and genetic influence [18-20]. Anaemia, low zinc and Vitamin A levels have been observed in children with stunting from cross-sectional studies and this is catalysed by the presence of concomitant inflammation as indicated by the detection of acute phase reactants such as $\alpha-1$ acid glycoprotein $[21,22]$. However, the association of micronutrients specifically with $\mathrm{HC}$ in children has not been studied in the developing world where micronutrient deficiency among children is widely prevalent. A recent study from rural Bangladesh has highlighted that either WASH or nutrition imparted as an intervention independently, had an improvement on the HC Z-scores in children of the intervention arm when compared to their age-matched controls. However, no difference was seen when combined Water, sanitation and Hygiene (WASH) along with nutrition as a package was given to the intervention arm when compared to control arm. This implicates the influence of a complex array of factors on $\mathrm{HC}$ and anthropometry on the whole, direct and indirect, along with the inherent maternal and paternal influences [23].

This study aims to assess the burden of low $\mathrm{HC}(<-2$ SD) at birth and its progress during first 2 years of life among children residing in a semi-urban settlement of Vellore. The study also determined the effect of sociodemographic, parental characteristics and micronutrient status on $\mathrm{HC}$ of children during the first 2years of life.

\section{Methods \\ Study design}

The present study uses baseline data and serial $\mathrm{HC}$ measurements from the birth cohort of MAL-ED (The Aetiology, Risk Factors, and Interactions of Enteric Infections and Malnutrition and the Consequences for Child Health) study, a multi-country birth cohort study, which was established at eight sites and was led by the Fogarty International Centre of the National Institutes of Health and the Foundation for the National Institutes of Health [24]. The aim of the MAL-ED study was to study the multiple effects and impact of enteric infections and malnutrition on child growth, cognition, and response to early childhood vaccination.

\section{Setting}

Vellore town $\left(12.9^{\circ} \mathrm{N}, 79.1^{\circ} \mathrm{E}\right)$, situated about $137 \mathrm{~km}$ from the city of Chennai (capital of the state of Tamil Nadu in south India), was one of the eight sites of MALED study. The study site established at Vellore is a semiurban settlement that comprises of a stretch of densely populated eight neighbourhoods with a total population of around 13,000. This section of the predominantly urban poor is catered to for its health needs by the government UPHC (Urban Primary Heath Centre) and the LCECU (Low Cost Effective Care Unit), which is a part of the community out-reach programme of the Christian Medical College, Vellore. LCECU has been closely working in this area over the last few decades to improve health, and has been serving this community, enabling referrals to the hospital where necessary. The site established a birth cohort of infants who were born healthy 
and were recruited within a window period of 17 days following birth.

\section{Study period}

The study was carried over a period of 4 years from March 2010 and ended in February 2014. Enrolment was completed in February 2012 and the last child completed the 24-month follow-up in February 2014.

\section{Study participants}

The inclusion criteria were the child being born as a singleton, parent/primary caregiver of the child being a permanent resident of the study area and those willing to permit home visits by the designated field staff. Parents/primary caregivers of the child who were likely to be away from the study site for more than 30 days during the study, new-borns of teenage mothers, prolonged hospitalization of the neonate at birth, diagnosed with a chronic condition or enteropathy and those who weighed less than $1500 \mathrm{~g}$ at the time of enrolment were excluded from the study. An informed written consent was obtained from the parent/primary caregiver of the child after having explained to him/her the purpose of the study in the local language - Tamil, a Dravidian language spoken in Vellore and the rest of the state of Tamil Nadu.

The new-born infants were enrolled in the study and followed up between March 2010 to February 2014. Field workers who were residents of the same community were selected for the cohort follow-up, and this strengthened the establishment of a smooth and robust rapport with the families. The infants were followed up at home by the designated field worker at specific time points as per protocol. Sick infants or those needing physician care were referred to a study clinic established in the study area, and further to LCECU if needed.

\section{Sample size calculation}

A prior population survey was performed in the study area before the commencement of enrolment. Using the number of women in the reproductive age enumerated in the survey, it was estimated that approximately 200 infants would be born within the MAL-ED study area in the enrolment period of 2 years. This led to the enrolment of approximately 10 infants every month over a period of 2 years $[24,25]$.

\section{Study procedures and measurements}

Following enrolment in the study, date of birth, gender and birth weight of the children were recorded. A structured questionnaire was used to collect sociodemographic and parental characteristics that included paternal and maternal age, education and socio- economic status (SES). Parental body-mass-index (BMI), $\mathrm{HC}$ and maternal intelligence quotient (IQ) were measured and documented as per protocol (Fig. 1). Maternal age was grouped as young mother ( $\leq 23$ years) and older mother ( $>23$ years) using the median cut-off value. Parental education was categorised as uneducated, primary (1st - 5th grade), secondary (6th - 10th grade) and high school ( $>11$ th grade). SES was measured using the WAMI index (access to improved Water and sanitation, eight selected Assets, Maternal education and household Income), developed to measure SES across diverse settings of low-and middle-income countries [26]. The score further led to the stratification of SES into low, middle and high using tertiles of the overall score. Maternal and paternal body-mass-indices were categorized as underweight (BMI < 18.5), normal (BMI 18.5-24.9) and overweight (BMI $\geq 25$ ).

Birth weight was classified as normal, low and very low were if the birth weights were $>2.5 \mathrm{~kg}, 2-2.49 \mathrm{~kg}$ and $<1.99 \mathrm{~kg}$ respectively. Anthropometry including head circumference (HC) (occipito-frontal diameter) of the child were measured at 3 time points: at recruitment, 12th month and 24th month as shown in Fig. 1. The measurements were performed and recorded by a trained study nurse and was measured to the nearest 0.1 $\mathrm{cm}$ by a non-expandable $\mathrm{HC}$ measuring band made of synthetic Teflon material. HC in children was classified using the WHO head circumference-for-age Z-scores [27]. Low $\mathrm{HC}$ in these children was defined as a measurement less than -2 SD. Wasting in the child was defined as weight-for-height $(\mathrm{W} / \mathrm{H})$ below $-2 \mathrm{SD}$ and stunting as height-for-age (H/A) below - 2 SD using the WHO Child Growth Standards median [28]. Paternal and maternal $\mathrm{HC}$ measurements were categorized as low and normal using the median cut-off due to lack of standard HC reference charts for Indian adult population [29]. Maternal intelligence was assessed by the study psychologist using the Ravens Combined Matrices Score (RCM) [30]. The RCM scores classified the mothers as those with low IQ who scored less than or equal to 33rd centile and normal or high IQ with scores more than 33rd centile. Cognition in children was assessed using the Bayley's scale at 6th, 15th and 24th month [31]. Micro-nutrient status of the children that incorporated levels of haemoglobin ( $\mathrm{g} \%$ ), ferritin ( $\mathrm{ng} /$ $\mathrm{ml})$, retinol $(\mathrm{g} / \mathrm{L})$, transferrin receptor $(\mathrm{mg} / \mathrm{L})$ and zinc $(\mu \mathrm{g} / \mathrm{dL})$ were quantified by serology collected at 7 th and 15 th month of age. In conjunction, $\alpha-1$-acid glycoprotein $(\mathrm{mg} / \mathrm{dL})$, was measured, the presence of which is a surrogate marker for active inflammation underlying subclinical infections and can lead to low levels of micronutrients in children [32]. The azide methaemoglobin method was employed for Haemoglobin estimation using a Hemocue (a battery driven photometer with 


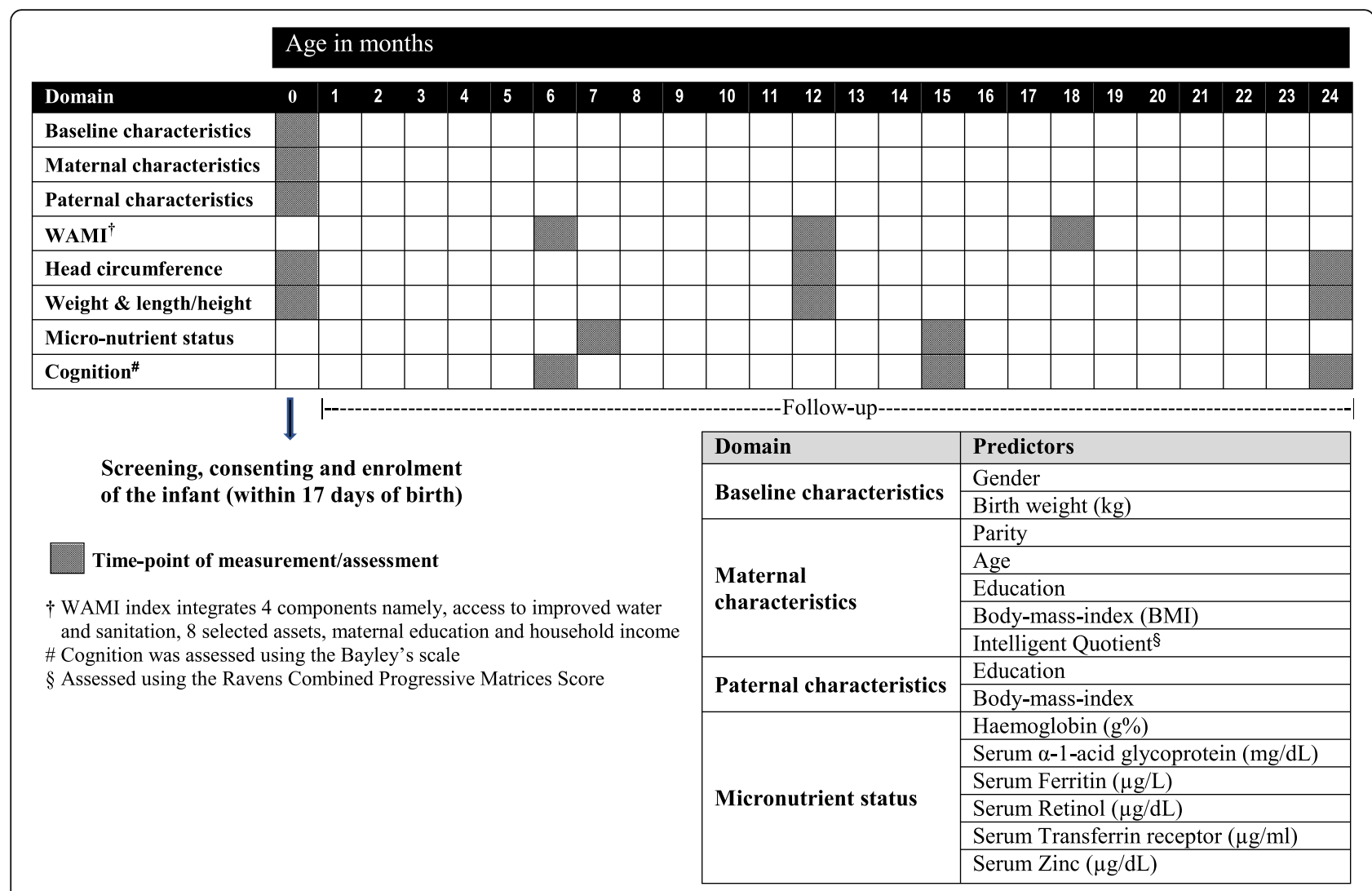

Fig. 1 Schematic representation of the study flow with follow-up time-points of recording baseline, paternal and maternal characteristics, weight, length/height, head circumference and assessment of micronutrient status

disposable cuvettes) and anaemia was defined using the World Health Organisation's definition of Haemoglobin less than $11 \mathrm{~g} / \mathrm{dL}$ [33]. Serum ferritin (male: 22-322 ng/ $\mathrm{ml}$; female: $10-290 \mathrm{ng} / \mathrm{ml})$, transferrin receptor $(1.9-5$ $\mathrm{mg} / \mathrm{L})$, zinc $(75-120 \mu \mathrm{g} / \mathrm{dL})$ and $\alpha$-1-acid glycoprotein (50-200 mg/dL) were classified as low and normal using standard references [34, 35]. Serum retinol was estimated using High Performance Liquid Chromatography (HPLC) and a level $<0.2 \mathrm{~g} / \mathrm{L}$ was considered as low [36].

\section{Statistical analysis}

Data were entered using a double-entry database application and stored at the Data Coordinating Center (DCC) of MAL-ED established at the Fogarty International Center [24]. All analyses were performed using Stata version 13 (StataCorp. 2013. Stata Statistical Software: Release 13. College Station, TX: StataCorp LP). Descriptive statistics were computed and presented as proportions along with $p$-values within each variable. $\mathrm{HC}$, stunting $(\mathrm{H} / \mathrm{A})$ and wasting $(\mathrm{W} / \mathrm{H})$ were calculated as proportions less that $-2 \mathrm{SD}$. A bi-variate analysis was performed to investigate or identify relationships between $\mathrm{HC}$ and socio-demographic variables, parental characteristics and micronutrient levels in the infant using Chi-square test, and odds ratios (OR) as well as 95\% confidence intervals (CI). A bivariate analysis was also performed to study association between $\mathrm{HC}$ and stunting measured at all three time-points, to further generate ORs. To adjust for confounders, the significant variables by bivariate analysis were modelled using a multivariable logistic regression analysis and the adjusted odds ratios (AORs) with 95\% confidence intervals (CI) were estimated. All variables in the regression model were imputed as categorical variables except paternal and maternal $\mathrm{HC}$ which were used as continuous variables. $P$-values presented are two-sided and $p$-value $<$ 0.05 was considered as statistically significant. We used Hosmer-Lemeshow goodness-of fit-test to assess the model fit. The test (Chi-square value $=3.20, p=0.92$ ), suggested that the model showed a good fit for the covariates used. Also, we measured the area under the curve (AUC) which showed a value of 0.7188 substantiating the model with a good fit.

\section{Results}

A total of 301 pregnant women (in their third trimester) consented to participate in the study and were followed until delivery. Following delivery, 251 infants were 
enrolled in the study. The 50 infants who thereby did not participate in the study comprised of 10 infants whose mothers withdrew consent following delivery and 40 infants did not meet the inclusion criteria. Overall, 228 (90.9\%) children completed the 24th month followup with 23 (9.1\%) children accounting for lost-to-follow, of who 15 (65.2\%) had migrated from the study area.

The baseline, paternal and maternal characteristics are presented in Table 1 . Of the 228 children, there were 105 (46\%) males and 123 (54\%) females. A parity of more than two was documented for 91/226 (40\%) mothers. The mean birth weight of the cohort was 2.89
$\mathrm{kg}(\mathrm{SD}=0.44)$ with $32 / 223(14 \%)$ low birth weight and $5 / 223(2 \%)$ very low birth weight infants. The mean age of the mothers at the time of enrolment was 23.9 (SD = $4.2)$ years. The average paternal and maternal years of schooling were $6.91(\mathrm{SD}=3.81)$ and $6.38(\mathrm{SD}=3.81)$ years respectively with $26 / 226$ (11\%) mothers and $30 /$ 212 (14\%) fathers having had no formal schooling. The mean maternal body mass index (BMI) was 22.04 $(\mathrm{SD}=$ $3.95) \mathrm{kg} / \mathrm{m}^{2}$ with $46 / 226(20 \%)$ mothers being underweight and 48/226 (21\%) overweight. Similarly, mean paternal body mass index (BMI) was $23.01(\mathrm{SD}=4.25) \mathrm{kg} /$ $\mathrm{m}^{2}$ with 20/205 (10\%) fathers being underweight and 54/

Table 1 Baseline, maternal and paternal characteristics of the study participants $(N=228)$

\begin{tabular}{|c|c|c|c|c|c|}
\hline Variable & & Category & $n$ & $\%$ & $p$-value \\
\hline \multirow[t]{2}{*}{ Gender $(n=228)$} & & Male & 105 & 46 & 0.23 \\
\hline & & Female & 123 & 54 & \\
\hline \multirow[t]{3}{*}{ Birth weight $(\mathrm{kg})(n=223)$} & & Very Low Birth weight $(<1.99$ kg) & 5 & 2 & $<0.001$ \\
\hline & & Low birth weight (2-2.49 kg) & 32 & 14 & \\
\hline & & Normal birth weight ( $\geq 2.5 \mathrm{~kg}$ ) & 186 & 84 & \\
\hline \multirow[t]{6}{*}{ Socio-economic status $\left(\mathrm{WAMI}^{\mathrm{a}}\right)$} & 6th month $(n=225)$ & Low ( $\leq 33$ rd centile) & 69 & 31 & $<0.001$ \\
\hline & & Middle and High (> 33rd centile) & 156 & 69 & \\
\hline & 12th month $(n=228)$ & Low $(\leq 33$ rd centile) & 74 & 32 & $<0.001$ \\
\hline & & Middle and High (> 33rd centile) & 154 & 68 & \\
\hline & 18th month $(n=228)$ & Low ( $\leq 33$ rd centile) & 72 & 32 & $<0.001$ \\
\hline & & Middle and High (> 33rd centile) & 156 & 68 & \\
\hline \multirow[t]{2}{*}{ Parity of the mother $(n=226)$} & & $>2$ & 91 & 40 & $<0.001$ \\
\hline & & $\leq 2$ & 135 & 60 & \\
\hline \multirow[t]{2}{*}{ Age of the mother $(n=226)$} & & $<23$ years & 96 & 42 & 0.109 \\
\hline & & $\geq 23$ years & 130 & 58 & \\
\hline \multirow[t]{4}{*}{ Mother's education $(n=226)$} & & No schooling & 26 & 11 & $<0.001$ \\
\hline & & Primary (1st to 5 th grade) & 54 & 24 & \\
\hline & & Secondary (6th to 10th grade) & 110 & 49 & \\
\hline & & High school (>11th grade) & 36 & 16 & \\
\hline \multirow[t]{4}{*}{ Father's education $(n=212)$} & & No schooling & 30 & 14 & $<0.001$ \\
\hline & & Primary (1st to 5 th grade) & 56 & 26 & \\
\hline & & Secondary (6th to 10th grade) & 109 & 52 & \\
\hline & & High school (>11th grade) & 17 & 8 & \\
\hline \multirow[t]{3}{*}{ Mother's BMI $(n=226)$} & & Under-weight $(<$ 18.5) & 46 & 20 & $<0.001$ \\
\hline & & Normal (18.5-24.9) & 132 & 59 & \\
\hline & & Over weight $(\geq 25)$ & 48 & 21 & \\
\hline \multirow[t]{3}{*}{ Father's BMI $(n=205)$} & & Under-weight $(<18.5)$ & 20 & 10 & $<0.001$ \\
\hline & & Normal (18.5-24.9) & 131 & 64 & \\
\hline & & Over weight $(\geq 25)$ & 54 & 26 & \\
\hline \multirow[t]{2}{*}{ Mother's IQ $\left(\mathrm{RCM}^{\mathrm{b}}\right)(n=228)$} & & Low $(\leq 33$ rd centile) & 81 & 36 & $<0.001$ \\
\hline & & Normal and High (> 33rd centile) & 147 & 64 & \\
\hline
\end{tabular}

${ }^{a}$ Socio-economic index that integrates 4 components namely, access to improved water and sanitation, 8 selected assets, maternal education and household income

${ }^{\mathrm{b}}$ Ravens Combined Matrices Score

data in bold represents $p$-value $<0.05$ 
205 (26\%) overweight. The maternal IQ assessment showed that $81 / 228$ (36\%) mothers scored within the lower third of the tertile. There was no variation in the WAMI scores over the 3 time points of measurement with 69 (31\%) infants falling within the lower tertile at the first assessment (6th month).

The mean maternal and paternal $\mathrm{HC}( \pm \mathrm{SD})$ were $51.63(1.57) \mathrm{cm}$ and $53.3(1.47) \mathrm{cm}$ respectively. The mean $\mathrm{HC}( \pm \mathrm{SD})$ of the infants at recruitment (1st month), 12th month and 24th month were 33.37 (1.29) $\mathrm{cm}, 42.76(1.23) \mathrm{cm}$ and $44.9(1.22) \mathrm{cm}$ respectively (Table 2). About a third of the infants $(75 / 228)$ had HC less than -2 SD at first month of life. This was followed by about 51.8 and $51.5 \%$ of the cohort progressing to have $\mathrm{HC}<-2 \mathrm{SD}$ measured at the 12th month and 24th month respectively (Table 2, Fig. 2). Among the children with a low $\mathrm{HC}$ at recruitment, $47.5 \%$ (56) were males and $52.5 \%$ (62) were females with no significant difference $[p$-value $=0.705, \mathrm{OR}=0.9(0.51-1.570)]$. Low $\mathrm{HC}$ measurements at all three time-points were observed for $21.6 \%(46 / 222)$ infants, with normal HC measurements being observed for $34.2 \%(76 / 222)$ children at all timepoints of measurement in the cohort. Stunting was observed in $15.8,31.4$ and $44.5 \%$ of the cohort at 1 st month, 12th month and 24th month respectively with 19.2, 15.5 and $11 \%$ being wasted at the same timepoints. Low $\mathrm{HC}$ was observed in $37.3 \%$ [ $p$-value $<0.001$, $\mathrm{OR}=10.8(4.6-25.3)], \quad 57.3 \% \quad[p$-value $<0.001, \quad \mathrm{OR}=$ $3.1(1.7-5.7)]$ and $44.4 \%[p$-value $<0.001, \mathrm{OR}=2.6(1.5-$ 4.4)] of children with stunting at 1st month, 12th month and 24th month respectively. Similarly, low $\mathrm{HC}$ was seen in $36.6 \%$ [ $p$-value $<0.001, \mathrm{OR}=4.6(2.2-9.3)], 23.9 \%[p-$ value $<0.001, \mathrm{OR}=4.6(1.9-11)]$ and $17.1 \%$ [ $p$-value $<$ $0.05, \mathrm{OR}=4.3(1.6-12)]$ of children with wasting at 1 st month, 12th month and 24th month respectively (Table 3).

More than half of the children were anaemic at 7th and 15th month of age (Table 4). $\alpha$-1-acid glycoprotein level was found to be elevated in 36 and $42 \%$ of the infants at 7 th and 15th month respectively. Low serum ferritin was observed in a quarter of the children at the 7 th month that significantly increased to $59 \%$ by the 15 th month. Low serum retinol and Zinc levels were present in 19 and $51 \%$ of the infants respectively at the 7 th month but at the 15th month, the number of children with low serum retinol declined to $13 \%$. However, the

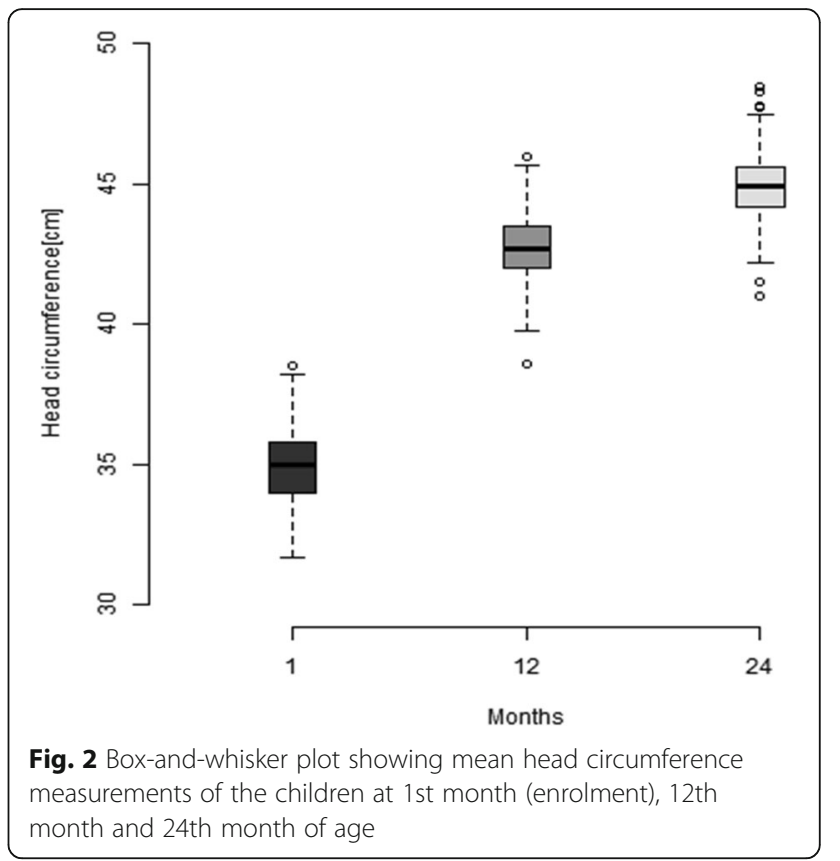

number of children with low serum Zinc level significantly increased to 73\%. An abnormal level of Transferrin receptor level was seen in $37 \%$ of the infants which remained unchanged when measured at the 15th month.

Bivariate analysis of low $\mathrm{HC}$ at the end of 12th month $(<-2 \mathrm{SD})$ with the baseline characteristics and micronutrient status of the infants showed a significant association with low socioeconomic status, low paternal and maternal $\mathrm{HC}$ and a low maternal IQ (Table 5). Among the infants who had a $\mathrm{HC}<-2 \mathrm{SD}$ at first month, $45.3 \%$ (34/75) showed poor cognition (<33rd centile) measured at 6th month when compared to those with a normal $\mathrm{HC}$, however this was not statistically significant (Chi-square $=0.002, p$-value $=0.93$ ). At 1 year of age, $32.4 \%(38 / 117)$ children with $\mathrm{HC}<-2$ SD had poor cognition and there was no significant association with the 15th month cognition scores (Chi-square $=0.026$, $p$ value $=0.87$ ). No significant association was elicited between low $\mathrm{HC}$ and poor cognition $(35 / 117)$ measured at 24th month (Chi-square $=0.567, p$-value $=0.45)$.

Multivariable logistic regression analysis for the significant predictors of low $\mathrm{HC}$ at 12th month $(n=190)$ is shown in Table 6 and represented in Fig. 3. Multivariable regression analysis showed that maternal and paternal

Table 2 Head circumference $(\mathrm{HC})$ measurements, stunting and wasting in the cohort at 1st, 12th and 24th month of age

\begin{tabular}{llllll}
\hline $\begin{array}{l}\text { Time point of } \\
\text { measurement }\end{array}$ & $\begin{array}{l}\text { Mean HC in } \mathrm{cm} \\
(\mathrm{SD})\end{array}$ & $\begin{array}{l}\text { Mean HC Z-score } \\
(\mathrm{SD})\end{array}$ & $\begin{array}{l}\text { HC less than }-2 \text { SD } \\
(\%)\end{array}$ & $\begin{array}{l}\text { Stunting less than }-2 \text { SD } \\
(\%)\end{array}$ & $\begin{array}{l}\text { Wasting less than - 2 SD } \\
(\%)\end{array}$ \\
\hline 1st month $(n=228)$ & $33.37(1.29)$ & $-1.50(1.01)$ & $75(32.9)$ & $36(15.8)$ & $43(19.2)$ \\
12th month $(n=226)$ & $42.76(1.23)$ & $-2.02(0.80)$ & $117(51.8)$ & $71(31.4)$ & $35(15.5)$ \\
24th month $(n=227)$ & $44.9(1.22)$ & $-2.00(0.78)$ & $117(51.5)$ & $101(44.5)$ & $25(11)$ \\
\hline
\end{tabular}


Table 3 Bivariate analysis of head circumference $(\mathrm{HC})$ with stunting and wasting at 1st, 12th and 24th month of age

\begin{tabular}{|c|c|c|c|c|c|c|c|c|c|}
\hline \multicolumn{2}{|c|}{ Time point of measurement } & \multicolumn{2}{|l|}{ Stunting $(\mathrm{H} / \mathrm{A})$} & \multirow[t]{2}{*}{$p$-value } & \multirow{2}{*}{$\begin{array}{l}\text { OR }(95 \% \\
\mathrm{Cl})\end{array}$} & \multicolumn{2}{|l|}{ Wasting $(\mathrm{W} / \mathrm{H})$} & \multirow[t]{2}{*}{$p$-value } & \multirow{2}{*}{$\begin{array}{l}\text { OR } \\
(95 \% \\
\mathrm{Cl})\end{array}$} \\
\hline & & $\begin{array}{l}\text { Stunting }<-2 \text { SD } \\
(\%)\end{array}$ & $\begin{array}{l}\text { No stunting } \\
(\%)\end{array}$ & & & $\begin{array}{l}\text { Wasting }<-2 \text { SD } \\
(\%)\end{array}$ & $\begin{array}{l}\text { No wasting } \\
(\%)\end{array}$ & & \\
\hline \multirow[t]{2}{*}{ 1st month $(n=228)$} & Low HC & $28(37.3)$ & $47(62.7)$ & \multirow[t]{2}{*}{$<0.001$} & \multirow{2}{*}{$\begin{array}{l}10.8 \\
(4.6- \\
25.3)\end{array}$} & $26(36.6)$ & $45(63.4)$ & \multirow[t]{2}{*}{$<0.001$} & \multirow{2}{*}{$\begin{array}{c}4.6 \\
(2.2- \\
9.3)\end{array}$} \\
\hline & $\begin{array}{l}\text { Normal } \\
\mathrm{HC}\end{array}$ & $8(5.2)$ & $145(94.8)$ & & & $17(11.1)$ & $136(88.9)$ & & \\
\hline \multirow{2}{*}{$\begin{array}{l}\text { 12th month }(n= \\
\text { 226) }\end{array}$} & Low HC & $50(42.7)$ & $67(57.3)$ & \multirow[t]{2}{*}{$<0.001$} & \multirow{2}{*}{$\begin{array}{c}3.1 \\
(1.7-5.7)\end{array}$} & $28(23.9)$ & $89(76.1)$ & \multirow[t]{2}{*}{$<0.001$} & \multirow{2}{*}{$\begin{array}{c}4.6 \\
(1.9-11)\end{array}$} \\
\hline & $\begin{array}{l}\text { Normal } \\
\mathrm{HC}\end{array}$ & $21(19.3)$ & $88(80.7)$ & & & $7(6.4)$ & $102(93.6)$ & & \\
\hline \multirow{2}{*}{$\begin{array}{l}\text { 24th month ( } n= \\
\text { 227) }\end{array}$} & Low HC & $65(55.6)$ & $52(44.4)$ & \multirow[t]{2}{*}{$<0.001$} & \multirow{2}{*}{$\begin{array}{c}2.6 \\
(1.5-4.4)\end{array}$} & $20(17.1)$ & $97(82.9)$ & \multirow[t]{2}{*}{$<0.05$} & \multirow{2}{*}{$\begin{array}{c}4.3 \\
(1.6-12\end{array}$} \\
\hline & $\begin{array}{l}\text { Normal } \\
\mathrm{HC}\end{array}$ & $74(32.7)$ & $36(67.3)$ & & & $5(4.5)$ & $105(95.5)$ & & \\
\hline
\end{tabular}

data in bold represents $p$-value $<0.05$

$\mathrm{HC}$ were significantly associated with the $\mathrm{HC}$ attained by the infant at the end of 12 th month. However, the above was not observed when the same predictors were compared with the $\mathrm{HC}$ measured at 24th month of age.

\section{Discussion}

This is a prospective birth cohort study to estimate and examine factors influencing low $\mathrm{HC}$ in the first 2years of life in a semi-urban settlement of south India. This intensively followed-up cohort had a drop-out rate of less than $10 \%$ and no significant differences were observed between the baseline characteristics of children who were lost to follow-up or for those with missing data, with the cohort that completed the study follow-up at 24 months (Additional file 1: Table S7). We observed that there were no gender differences in $\mathrm{HC}$ measurements at 1 month of age and this was similar to the observation made by Veena et al. [5]. Our study showed one-third of the children started with a low $\mathrm{HC}$ at birth. This proportion in the cohort increased to $50 \%$ with low $\mathrm{HC}$ at the end of 1 year, and thereon persisted with no further change in the cohort at 2 years of life. Hence, this is a significant one-third of the population beginning very early in life with a reduced $\mathrm{HC}$ and is substantiated by the fact that Indian children start off right in-utero with a low $\mathrm{HC}$ [37]. The cohort had about a fifth of the children who recorded low $\mathrm{HC}$ at birth and continued to have low $\mathrm{HC}$ at all time-points until 2 years of age. This indicates that growth faltering that began early inutero can continue to persist without catching up upto the first 2 years of life. This could further herald an array of effects of stunting that encompass linear growth failure in children such as repeated infections, poor cognition and further, chronic diseases in adulthood [38]. Further, infants who were stunted at 1 st month had 10.8 times higher odds of having low $\mathrm{HC}$ [28]. This was also true at the end of first and second year with stunted infants having 3.1 and 2.6 times higher odds of low $\mathrm{HC}$ respectively.

$\mathrm{HC}$ is an indicator of stunting or chronic malnutrition and our study has not only reflected the stunting proportions similar to the proportions estimated by the

Table 4 Micronutrient status of the infants at 7th and 15th month of birth

\begin{tabular}{|c|c|c|c|c|c|c|c|c|}
\hline \multirow[t]{2}{*}{ Variable } & \multirow[t]{2}{*}{ Category } & \multicolumn{3}{|c|}{ 7th month } & \multicolumn{3}{|c|}{ 15th month } & \multirow[t]{2}{*}{$p$-value } \\
\hline & & $n$ & Freq & $\%$ & $n$ & Freq & $\%$ & \\
\hline \multirow[t]{2}{*}{ Haemoglobin $(g \%)(n=228)$} & Anaemia & 228 & 117 & 51.3 & 227 & 128 & 56.1 & 0.20 \\
\hline & Normal & & 111 & 48.7 & & 99 & 44 & \\
\hline \multirow[t]{2}{*}{ a-1-acid glycoprotein (mg/dL) $(n=212)$} & Elevated & 212 & 76 & 35.8 & 225 & 94 & 42 & 0.33 \\
\hline & Normal & & 136 & 64.2 & & 131 & 58 & \\
\hline \multirow[t]{2}{*}{ Ferritin $(\mathrm{ng} / \mathrm{ml})(n=225)$} & Low & 225 & 52 & 23.1 & 221 & 130 & 59 & $<0.001$ \\
\hline & Normal & & 173 & 76.9 & & 91 & 41 & \\
\hline \multirow[t]{2}{*}{ Retinol $(\mu \mathrm{g} / \mathrm{dL})(n=204)$} & Low & 204 & 40 & 19.6 & 226 & 29 & 13 & $<0.01$ \\
\hline & Normal & & 164 & 80.4 & & 197 & 87 & \\
\hline \multirow[t]{2}{*}{ Transferrin receptor $(\mathrm{mg} / \mathrm{L})(n=214)$} & Low & 214 & 80 & 37.4 & 225 & 80 & 36 & 0.91 \\
\hline & Normal & & 134 & 62.6 & & 145 & 64 & \\
\hline \multirow[t]{2}{*}{ Serum Zinc $(\mu \mathrm{g} / \mathrm{dL})(n=217$} & Low & 217 & 110 & 50.7 & 226 & 165 & 73 & $<0.001$ \\
\hline & Normal & & 107 & 49.3 & & 61 & 27 & \\
\hline
\end{tabular}


Table 5 Bi-variate analysis of baseline, maternal and paternal characteristics; micro-nutrient status and cognition with $\mathrm{HC}$ measurement (12th month)

\begin{tabular}{|c|c|c|c|c|c|}
\hline \multirow[t]{2}{*}{ Predictor } & \multicolumn{2}{|c|}{ Head circumference $(\mathrm{cm})$} & \multirow{2}{*}{$\begin{array}{l}\text { Chi- } \\
\text { squared } \\
\text { value }\end{array}$} & \multirow{2}{*}{$\begin{array}{l}p- \\
\text { value }\end{array}$} & \multirow{2}{*}{$\begin{array}{l}\text { OR } \\
(95 \% \mathrm{Cl})\end{array}$} \\
\hline & $<-2$ SD (\%) & Normal (\%) & & & \\
\hline Low birth weight $(<2.5 \mathrm{~kg})$ & $93(50)$ & $21(58.3)$ & 0.838 & 0.360 & $1.40(0.64-3.10)$ \\
\hline WAMI (6th month) (<33rd centile) & $43(37.1)$ & $26(24.1)$ & 4.431 & 0.035 & $1.86(1.01-3.47)$ \\
\hline WAMI (12th month) (<33rd centile) & $46(39)$ & $28(25.7)$ & 4.55 & 0.033 & $1.85(1.01-3.40)$ \\
\hline WAMI (24th month) (<33rd centile) & $31(26.5)$ & $18(16.7)$ & 3.18 & 0.074 & $1.80(0.89-3.68)$ \\
\hline Low maternal HC (cm) & $72(62.6)$ & $43(42.2)$ & 9.07 & 0.003 & $2.29(1.28-4.11)$ \\
\hline Low paternal HC (cm) & $60(56.1)$ & 39 (39.8) & 5.42 & 0.02 & $1.93(1.06-3.50)$ \\
\hline Parity of the mother $(>2)$ & $68(59.6)$ & $65(58.6)$ & 0.02 & 0.87 & $0.96(0.54-1.68)$ \\
\hline Age of the mother (<23 years) & $48(41.4)$ & $47(43.1)$ & 0.07 & 0.80 & $0.93(0.53-1.63)$ \\
\hline Low maternal education & $46(39.7)$ & $34(31.2)$ & 1.75 & 0.185 & $1.45(0.80-2.61)$ \\
\hline Low paternal education & $48(42.8)$ & $38(38.4)$ & 0.43 & 0.509 & $1.20(0.66-2.17)$ \\
\hline Low maternal BMI & $27(23.1)$ & $18(16.7)$ & 1.44 & 0.23 & $1.50(0.73-3.10)$ \\
\hline Low paternal BMI & $13(12.2)$ & $7(7.1)$ & 1.45 & 0.23 & $1.79(0.63-5.59)$ \\
\hline Low maternal IQ (<33rd centile) & $52(44.1)$ & $28(25.7)$ & 8.38 & 0.004 & $2.28(1.25-4.17)$ \\
\hline Exclusively breastfeeding ( $\leq 4$ month) & $109(93.2)$ & $97(89)$ & 1.42 & 0.49 & $1.68(0.66-4.29)$ \\
\hline Anaemia & $62(53)$ & $55(51)$ & 0.09 & 0.75 & $1.08(0.62-1.89)$ \\
\hline Elevated a-1-acid glycoprotein (mg/dL) ${ }^{a}$ & $41(37.9)$ & $35(33.9)$ & 0.362 & 0.55 & $1.18(0.65-2.17)$ \\
\hline Low Ferritin $(\mu \mathrm{g} / \mathrm{L})^{a}$ & $31(26.7)$ & $21(19.4)$ & 1.66 & 0.19 & $1.51(0.77-2.99)$ \\
\hline Low Retinol $(\mu \mathrm{g} / \mathrm{dL})^{\mathrm{a}}$ & $21(20.2)$ & 19 (19.2) & 0.032 & 0.85 & $1.06(0.50-2.26)$ \\
\hline Low Transferrin receptor $(\mu \mathrm{g} / \mathrm{ml})^{\mathrm{a}}$ & $66(60.6)$ & $67(64.4)$ & 0.34 & 0.56 & $0.84(0.46-1.53)$ \\
\hline Low Serum Zinc $(\mu \mathrm{g} / \mathrm{dL})^{a}$ & $61(54.4)$ & $48(46.1)$ & 1.49 & 0.22 & $1.39(0.79-2.47)$ \\
\hline
\end{tabular}

${ }^{a}$ Measured at 7th month

data in bold represents $p$-value $<0.05$

Table 6 Predictors of low head circumference $(H C)$ at 12th month $(n=190)$ using multivariable logistic regression analysis

\begin{tabular}{|c|c|c|c|c|}
\hline Predictor & & $\beta$-coefficient $(95 \% \mathrm{Cl})$ & Adjusted OR (95\% Cl) & $p$-value \\
\hline \multirow[t]{2}{*}{ Birth weight } & $<2.5 \mathrm{~kg}$ & $0.491(-0.344$ to 1.325$)$ & 1.633 (0.709 to 3.764$)$ & 0.249 \\
\hline & $\geq 2.5 \mathrm{~kg}$ & - & - & \\
\hline \multirow[t]{2}{*}{ WAMI (6th month) } & $<33$ rd centile & $0.444(-0.306$ to 1.195$)$ & 1.560 (0.736 to 3.307$)$ & 0.246 \\
\hline & $\geq 33$ rd centile & - & - & \\
\hline Low paternal $\mathrm{HC}^{\mathrm{a}}$ & & $-0.308(-0.544$ to -0.073$)$ & 0.734 (0.581 to 0.930$)$ & 0.01 \\
\hline \multirow[t]{2}{*}{ Paternal BMI } & Low & $0.033(-1.079$ to 1.147$)$ & 1.034 (0.340 to 3.149 ) & 0.952 \\
\hline & Normal & - & - & \\
\hline Low maternal $\mathrm{HC}^{\mathrm{a}}$ & & $-0.275(-0.504$ to -0.046$)$ & 0.759 (0.604 to 0.954$)$ & 0.018 \\
\hline \multirow[t]{2}{*}{ Maternal BMI } & Low & $0.110(-0.727$ to 0.947$)$ & 1.116 (0.483 to 2.579$)$ & 0.797 \\
\hline & Normal & - & - & \\
\hline \multirow[t]{2}{*}{ Maternal IQ } & $<33$ rd centile & $-0.665(-1.375$ to 0.044$)$ & 0.514 (0.253 to 1.046$)$ & 0.066 \\
\hline & $\geq 33$ rd centile & - & - & \\
\hline \multirow[t]{2}{*}{ Exclusive breast feeding } & $<4$ months & $1.187(-0.107$ to 2.483 & 3.279 (0.898 to 11.977$)$ & 0.072 \\
\hline & $\geq 4$ months & - & - & \\
\hline \multirow[t]{2}{*}{ Serum Zinc level ( $\mu \mathrm{g} / \mathrm{dL})$} & Low & $0.441(-0.194$ to 1.078$)$ & 1.556 (0.823 to 2.939) & 0.173 \\
\hline & Normal & - & - & \\
\hline
\end{tabular}

${ }^{\mathrm{a}} \mathrm{HC}$ was used as a continuous variable for regression analysis data in bold represents $p$-value $<0.05$ 


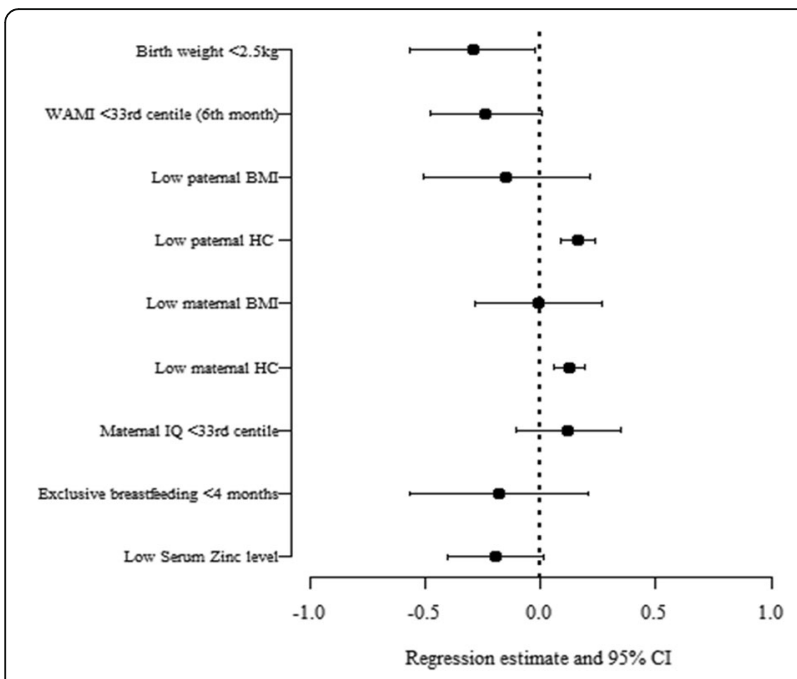

Fig. 3 Multivariate regression analysis of the significant predictors of 12th month head circumference measurement

WHO for the South-east Asian region as well as by the National Family Health Suryey-4, but also elicited strong association with $\mathrm{HC}[3,39]$. Also, children who started early in life with a normal $\mathrm{HC}$, showed lower HC-forage, later by their first birthday. This is probably because $\mathrm{HC}$ is also influenced by other factors such as exclusive breast-feeding and complementary feeding practices that play a pivotal role in the first year of life, though our study did not elicit a significant difference with $\mathrm{HC}$ and exclusive breast feeding $[16,40]$. Following the first year of life, HC probably remains unaltered as observed in our study. The low HC established by the end of first year continues to persist and probably co-exists with concurrent malnutrition in these children. This emphasizes that $\mathrm{HC}$ at birth predominantly determines $\mathrm{HC}$ later with the first year of life being a highly critical period for achieving optimal growth. Also, the first year of life is a golden period to intervene and help children catch-up growth. Hence $\mathrm{HC}$ measurement at birth, and further serial measurements up to the first year of life is a pragmatic and a highly informative parameter to monitor children who could potentially slip into the cascade of malnutrition, as this is the best period when interventions are plausible and effective.

Our study showed that socio-economic status had a significant association with a low $\mathrm{HC}$ and this is similar to the findings from a study in eastern India [4]. High prevalence of maternal undernutrition that sets in as early as adolescence in girls from impoverished communities could be a biologically plausible explanation for this [41]. Assuming a normal micronutrient status to start with at birth, we measured micronutrient status and inflammation at the 7th month. Anaemia was observed in about half the infants but did not show significant association with low HC. Underlying inflammation flagged by an elevated $\alpha$-1-acid glycoprotein was seen in a third of the infants and this showed no significant differences between those with low and normal HC. Children who measured for normal $\mathrm{HC}$ at birth and later had not caught up with the expected $\mathrm{HC}$ could possibly be due to an enteropathy setting in early following birth as shown by a study on Zimbabwean children where enteropathy in the background of inflammation was associated with stunting [42]. However, our study did not elicit this. Low maternal IQ was found to be associated with low $\mathrm{HC}$ and this is compounded with findings from the same geographical area by Anoop et al. where low maternal intelligence was associated with malnutrition in infants [43]. Low paternal and maternal $\mathrm{HC}$ were the strongest associations with low $\mathrm{HC}$ in children in our study and this shows that apart from possible external exposures, it was the genetic influence that strongly determined $\mathrm{HC}$ in infants as put forth by Silventoinen et al. [44]. Overall, it can be said that parental characteristics encompassing parental nutritional status and their early exposure in-utero along with the living standards and economic conditions perhaps amalgamate directly or indirectly to influence the $\mathrm{HC}$ and thereby malnutrition in children. The unavailability of $\mathrm{HC}$ and length immediately following birth along with the gestational age that did not permit us to adjust our anthropometric measurements at all time-points, was a limitation for our study.

It can be concluded that $\mathrm{HC}$ measurements along with routine length/height and weight can play a pivotal role in predicting stunting as shown by the relationship between stunting and $\mathrm{HC}$ elicited by our study. Health systems in developing countries should thereby have a systematic approach to the recording of these simple yet vital measurements beginning from birth. Immunization visits provide a valuable opportunity to document $\mathrm{HC}$ along with weight and length measurements early in the first year of life. It is also simple tool where mothers can be taught to measure $\mathrm{HC}$ in their infants especially in difficult settings as demonstrated by studies where a high degree of agreement was elicited between the anthropometrist and parental measurements of $\mathrm{HC}$ [45]. Also, developed countries have established normative databases for head circumference of their populations that the developing countries lack [46]. Developing countries like India need to establish the same, as comparison and interpretation of its data with international charts may not be suitable to draw precise and valid conclusions for all ethnic settings [47, 48]. Establishing normative data on $\mathrm{HC}$ for Indian population could play a cardinal role in further understanding $\mathrm{HC}$ in the Indian setting and in the long, have policy implications on the timing and package of interventions to curb the problem of stunting. 


\section{Conclusion}

Children in the MAL-ED cohort established in the semiurban settlement of Vellore started their life with a reduced head circumference, and the numbers further increased by the end of 2 years. Further, children who recorded low head circumference at birth continued to have low circumference at all time-points until 2 years of age. Stunting was significantly associated with low head circumference in the first 2 years of life, hence proving as an important tool of measurement apart from length/height and weight to predict stunting. Paternal and maternal head circumference were significantly associated with a reduced head circumference in children indicating a strong genetic influence. There is a definite need for the establishment of normative data for head circumference for both children as well as adults for the Indian population. Head circumference measurement, often not utilised optimally, can be a very simple tool that can be used by mothers and caregivers for growth monitoring at homes thereby help in early detection of growth faltering.

\section{Additional file}

Additional file 1: Table S7. Comparison of baseline characteristics of the children who completed the two-year follow-up with those who were lost-to-follow up. (DOCX $19 \mathrm{~kb}$ )

\section{Abbreviations \\ Cl: Confidence Interval; HC: Head Circumference; HPLC: High Performance Liquid Chromatography; IQ: Intelligent Quotient; LCECU: Low Cost Effective Care Unit; MAL-ED: The Aetiology, Risk Factors, and Interactions of Enteric Infections and Malnutrition and the Consequences for Child Health study; OR: Odds-ratio; RCM: Raven's Combined Progressive Matrices instrument: SD: Standard Deviation; UHC: Urban Health Centre; WAMI: Socio-economic status index that includes access to improved water and sanitation, eight selected assets, maternal education, and household income; WHO: World Health Organization}

\section{Acknowledgements}

The authors thank the staff, parents and children of the MAL-ED Network for their important contributions.

\section{Authors' contributions}

$G K, A B, V R M, S M J, B K, S B, P R$ conceived the study, drafted the original protocol and provided critical revision of the final draft. VRM, SMJ, PR helped in setting up the study, field staff training and study coordination. SB and JDB supervised the laboratory assays. KNS, KR and AH did data collection and management, performed the statistical analysis and wrote the manuscript. All authors read and approved the final manuscript.

\section{Funding}

The Etiology, Risk Factors and Interactions of Enteric Infections and Malnutrition and the Consequences for Child Health and Development Project (MAL-ED) is a collaborative project supported by the Bill \& Melinda Gates Foundation, the Foundation for the National Institutes of Health, and the Fogarty International Center, National Institutes of Health. Funding bodies had no role in designing the study, collection, analysis, and interpretation of data, or in writing the manuscript.

\section{Availability of data and materials}

The datasets used and analysed during the current study are available from the corresponding author on reasonable request.

\section{Ethics approval and consent to participate}

The study that was approved by the ethics committee of Institutional Review Board (IRB), Christian Medical College, Vellore in India. Approval was also obtained from the Indian government's Health Ministry Screening Committee. Written informed consent was obtained from the mother/ primary caregiver of the study participant.

\section{Consent for publication}

Not applicable.

\section{Competing interests}

Venkata Raghava Mohan and Sudhir Babji are Associate Editors for BMC Public Health. The other authors declare that they have no competing interests.

\section{Author details}

'Division of Gastrointestinal Sciences, Christian Medical College, Vellore, Tamil Nadu, India. ${ }^{2}$ Rural Unit for Health and Social Affairs, Christian Medical College, Vellore, Tamil Nadu 632 209, India. ${ }^{3}$ Department of Clinical Biochemistry, Christian Medical College, Vellore, Tamil Nadu, India. ${ }^{4}$ Low Cost Effective Care Unit, Christian Medical College, Vellore, Tamil Nadu, India. ${ }^{5}$ Developmental Pediatric Unit, Christian Medical College, Vellore, Tamil Nadu, India. ${ }^{6}$ Department of Community Health, Christian Medical College, Vellore, Tamil Nadu, India.

Received: 21 August 2018 Accepted: 22 May 2019

Published online: 06 June 2019

\section{References}

1. de Onis M, Blössner M, Borghi E. Prevalence and trends of stunting among pre-school children, 1990-2020. Public Health Nutr. 2012;15(1):142-8.

2. GNR. Global Nutrition Report. Available from: https://globalnutritionreport. org/reports/2017-global-nutrition-report/. Accessed 29 Jan 2019.

3. National Family Health Survey, India. Available from: http://rchiips.org/NFHS/ factsheet_NFHS-4.shtml Accessed 29 Jan 2019.

4. Maiti S, Ali KM, Ghosh D, Paul S. Assessment of head circumference among pre-school children of Midnapore town, West Bengal using WHO (2007) recommended cut-off points. Int J Prev Med. 2012;3(10):742-4.

5. Veena SR, Krishnaveni GV, Wills AK, Kurpad AV, Muthayya S, Hill JC, et al. Association of birthweight and head circumference at birth to cognitive performance in 9-10-year-old children in South India: prospective birth cohort study. Pediatr Res. 2010;67(4):424-9.

6. Bartholomeusz HH, Courchesne E, Karns CM. Relationship between head circumference and brain volume in healthy normal toddlers, children, and adults. Neuropediatrics. 2002;33(5):239-41.

7. Lindley AA, Benson JE, Grimes C, Cole TM, Herman AA. The relationship in neonates between clinically measured head circumference and brain volume estimated from head CT-scans. Early Hum Dev. 1999;56(1):17-29.

8. Gale CR, O'Callaghan FJ, Bredow M, Martyn CN. Avon longitudinal study of parents and children study team. The influence of head growth in fetal life, infancy, and childhood on intelligence at the ages of 4 and 8 years. Pediatrics. 2006;118(4):1486-92.

9. Mraz KD, Green J, Dumont-Mathieu T, Makin S, Fein D. Correlates of head circumference growth in infants later diagnosed with autism spectrum disorders. J Child Neurol. 2007;22(6):700-13.

10. Tal G, Cohen A, Habib S, Tirosh E. Decreased head circumference velocity as related to developmental deficit in infancy. Pediatr Neurol. 2012;47(5):341-4.

11. Bouthoorn SH, van Lenthe FJ, Hokken-Koelega ACS, Moll HA, Tiemeier $\mathrm{H}_{\text {, }}$ Hofman A, et al. Head circumference of infants born to mothers with different educational levels; the generation R study. PLoS One. 2012;7(6): e39798.

12. Tong $S$, Baghurst $P$, Vimpani $G$, McMichael A. Socioeconomic position, maternal IQ, home environment, and cognitive development. J Pediatr. 2007;151:284-8.

13. Olusanya BO. Maternal antecedents of infants with abnormal head sizes in Southwest Nigeria: a community-based study. J Fam Community Med. 2012;19(2):113-8.

14. Bove I, Miranda T, Campoy C, Uauy R, Napol M. Stunting, overweight and child development impairment go hand in hand as key problems of early infancy: Uruguayan case. Early Hum Dev. 2012;88(9):747-51. 
15. Donma MM, Donma O. The influence of feeding patterns on head circumference among Turkish infants during the first 6 months of life. Brain and Development. 1997;19(6):393-7.

16. Ferreira $H$ d S, Xavier Júnior AFS, de Assunção ML, Dos Santos EA, Horta BL. Effect of breastfeeding on head circumference of children from impoverished communities. Breastfeed Med. 2013;8(3):294-301.

17. Källén K. Maternal smoking during pregnancy and infant head circumference at birth. Early Hum Dev. 2000;58(3):197-204.

18. Osborne J, Havalad S, Hudson B, Hughes A. Effect of parental head circumference on that of the newborn child. Arch Dis Child. 1980;55(6): $480-2$.

19. Rice F, Thapar A. Estimating the relative contributions of maternal genetic, paternal genetic and intrauterine factors to offspring birth weight and head circumference. Early Hum Dev. 2010;86(7):425-32.

20. Ivanovic DM, Leiva BP, Pérez HT, Olivares MG, Díaz NS, Urrutia MSC, et al. Head size and intelligence, learning, nutritional status and brain development. Head, IQ, learning, nutrition and brain. Neuropsychologia. 2004;42(8):1118-31.

21. Marasinghe E, Chackrewarthy S, Abeysena C, Rajindrajith S. Micronutrient status and its relationship with nutritional status in preschool children in urban Sri Lanka. Asia Pac J Clin Nutr. 2015;24(1):144-51.

22. Tomkins A. Assessing micronutrient status in the presence of inflammation. J Nutr. 2003;133(5 Suppl 2):1649S-55S

23. Luby SP, Rahman M, Arnold BF, Unicomb L, Ashraf S, Winch PJ, et al. Effects of water quality, sanitation, handwashing, and nutritional interventions on diarrhoea and child growth in rural Bangladesh: a cluster randomised controlled trial. Lancet Glob Health. 2018;6(3):e302-15.

24. MAL-ED Network Investigators. The MAL-ED study: a multinational and multidisciplinary approach to understand the relationship between enteric pathogens, malnutrition, gut physiology, physical growth, cognitive development, and immune responses in infants and children up to 2 years of age in resource-poor environments. Clin Infect Dis. 2014;59(Suppl 4): S193-206.

25. John SM, Thomas RJ, Kaki S, Sharma SL, Ramanujam K, Raghava MV, et al. Establishment of the MAL-ED birth cohort study site in Vellore, southern India. Clin Infect Dis. 2014;59(Suppl 4):S295-9.

26. Psaki SR, Seidman JC, Miller M, Gottlieb M, Bhutta ZA, Ahmed T, et al. Measuring socioeconomic status in multicountry studies: results from the eight-country MAL-ED study. Popul Health Metrics. 2014;12(1):8.

27. World Health Organization. Child Growth Standards. Head circumferencefor-age. Available from: http://www.who.int/childgrowth/standards/hc_for_ age/en/ Accessed 29 Jan 2019.

28. World Health Organization. Nutrition Landscape Information System (NLIS) Country profile indicators. Interpretation Guide. Available from: https://www. who.int/nutrition/nlis_interpretation_guide.pdf Accessed 29 Jan 2019.

29. Bushby KM, Cole T, Matthews JN, Goodship JA. Centiles for adult head circumference. Arch Dis Child. J, Raven J., Court J. Manual for Raven's progressive matrices and vocabulary scales. Section 3, Standard progressive matrices (including the Parallel and Plus versions). 2000. Oxford: OPP Ltd; 2000 [cited 2018 Jul 16]. Available from: https://trove. nla.gov.au/version/211469979 Accessed 29 Jan 2019.

30. Raven J, Raven J., Court J. Manual for Raven's progressive matrices and vocabulary scales. Section 3, Standard progressive matrices (including the Parallel and Plus versions). 2000. Oxford: OPP Ltd; 2000 [cited 2018 Jul 16]. Available from: https://trove.nla.gov.au/version/211469979 Accessed 29 Jan 2019.

31. Bayley Scales of Infant Development, 3rd Edition - The Psychometrics Centre. Available from: https://www.psychometrics.cam.ac.uk/services/ psychometric-tests/bayley-scales Accessed 29 Jan 2019.

32. Stoltzfus RJ, Klemm R. Research, policy, and programmatic considerations from the biomarkers reflecting inflammation and nutritional determinants of Anemia (BRINDA) project. Am J Clin Nutr. 2017;106(Suppl 1):428S-34S.

33. World Health Organization. Iron deficiency Anaemia assessment, prevention, and control: a guide for programme managers. Available from: http://www. who.int/nutrition/publications/en/ida_assessment_prevention_control.pdf Accessed 29 Jan 2019

34. Wallach's interpretation of diagnostic tests. Available from: https://www. ncbi.nlm.nih.gov/nlmcatalog/101552348 Accessed 29 Jan 2019.

35. Tietz Textbook of Clinical Chemistry and Molecular Diagnostics - 5th Edition. Available from: https:/www.elsevier.com/books/tietz-textbook-of-clinical-chemistryand-molecular-diagnostics/burtis/978-0-323-08985-2 Accessed 29 Jan 2019.
36. ARUP Laboratories. Laboratory test directory. Vitamin A (Retinol), Serum or Plasma. Available from: http://ltd.aruplab.com/Tests/Pub/Print/0080525 Accessed 29 Jan 2019

37. Kinare AS, Chinchwadkar MC, Natekar AS, Coyaji KJ, Wills AK, Joglekar CV, et al. Patterns of fetal growth in a rural Indian cohort and comparison with a Western European population: data from the Pune maternal nutrition study. J Ultrasound Med. 2010;29(2):215-23.

38. de Onis M, Branca F. Childhood stunting: a global perspective. Matern Child Nutr. 2016;12(Suppl 1):12-26.

39. World Health Organization. Global Health Observatory data repository. Global and regional trends by UN regions, 1990-2025 - stunting: 19902025. Available from: http://apps.who.int/gho/data/view.main. NUTUNSTUNTINGv?lang=en Accessed 29 Jan 2019.

40. Prendergast AJ, Humphrey $\mathrm{JH}$. The stunting syndrome in developing countries. Paediatr Int Child Health. 2014;34(4):250-65.

41. Venkaiah K, Damayanti K, Nayak MU, Vijayaraghavan K. Diet and nutritional status of rural adolescents in India. Eur J Clin Nutr. 2002;56(11):1119-25.

42. Prendergast AJ, Rukobo S, Chasekwa B, Mutasa K, Ntozini R, Mbuya MNN, et al. Stunting is characterized by chronic inflammation in Zimbabwean infants. PLoS One. 2014;9(2):e86928.

43. Anoop S, Saravanan B, Joseph A, Cherian A, Jacob K. Maternal depression and low maternal intelligence as risk factors for malnutrition in children: a community based case-control study from South India. Arch Dis Child. 2004 89(4):325-9.

44. Silventoinen K, Sammalisto S, Perola M, Boomsma DI, Cornes BK, Davis C, et al. Heritability of adult body height: a comparative study of twin cohorts in eight countries. Twin Res. 2003;6:399-408.

45. Sullivan JC, Tavassoli T, Armstrong K, Baron-Cohen S, Humphrey A. Reliability of self, parental, and researcher measurements of head circumference. Mol Autism. 2014;5(1):2.

46. Wright CM, Inskip HM, Godfrey K, Williams AF, Ong KK. Monitoring head size and growth using the new UK-WHO growth standard. Arch Dis Child. 2011; 96(4):386-8.

47. Baxter P. Head size: WHOse growth charts? Dev Med Child Neurol. 2011 53(1):3-4.

48. Natale $\mathrm{V}$, Rajagopalan A. Worldwide variation in human growth and the World Health Organization growth standards: a systematic review. BMJ Open. 2014;4(1):e003735

\section{Publisher's Note}

Springer Nature remains neutral with regard to jurisdictional claims in published maps and institutional affiliations.

Ready to submit your research? Choose BMC and benefit from

- fast, convenient online submission

- thorough peer review by experienced researchers in your field

- rapid publication on acceptance

- support for research data, including large and complex data types

- gold Open Access which fosters wider collaboration and increased citations

- maximum visibility for your research: over $100 \mathrm{M}$ website views per year

At BMC, research is always in progress.

Learn more biomedcentral.com/submissions 